\title{
Aldol addition-cyclization reaction cascade on a platform of chiral Ni(II) complex of glycine schiff base
}

\author{
Yupiao Zou ${ }^{1}$, Zizhen Yin $^{1}$, Haibo Mei $^{1}$, Hiroyuki Konno ${ }^{2}$, Hiroki Moriwaki ${ }^{3}$, Vadim A. Soloshonok ${ }^{4,5 *}$ \\ and Jianlin $\operatorname{Han}^{1 *}$ \\ ${ }^{1}$ College of Chemical Engineering, Nanjing Forestry University, 159 Lonpan Road, Nanjing, 210037, China \\ ${ }^{2}$ Department of Biochemical Engineering, Graduate School of Science and Technology, Yamagata University, Yonezawa, Yamagata 992-8510, Japan \\ ${ }^{3}$ Hamari Chemicals Ltd., 1-19-40, Nankokita, Suminoe-ku, Osaka, 559-0034, Japan \\ ${ }^{4}$ Department of Organic Chemistry I, Faculty of Chemistry, University of the Basque Country UPV/EHU, Paseo Manuel Lardizábal 3, 20018 \\ San Sebastián, Spain \\ ${ }^{5}$ IKERBASQUE, Basque Foundation for Science, Maria Diaz de Haro 3, 48013 Bilbao, Spain
}

\begin{abstract}
Using platform of a new type of chiral Ni(II) complex of glycine Schiff base we designed addition-cyclization reaction cascade to explore aspects of kinetic/thermodynamic formation of the corresponding $(S)(2 S, 3 S) /(S)(2 S, 3 R)$ diastereomers. It was found that the final lactone products reflect the thermodynamic stereocontrol due to much greater rates of the reversible aldol addition vs. subsequent cyclization step. The observed $4 / 1(S)(2 S, 3 S) /(S)(2 S, 3 R)$ diastereoselectivity in the reactions of new type of $(S)$-Ni(II) complexes constitute an improvement over the previously reported $1.7 / 1$ ratio.
\end{abstract}

Keywords: asymmetric synthesis; aldol additions; tailor-made amino acids; Ni(II) complexes; Schiff bases; cascade/domino/tandem reaction.

\section{Introduction}

Tailor-made amino acids (AAs) [1] are in high demand in modern pharmaceutical industry. Along with fluorine [2], AAs' residues can be found in a growing number of marketed drugs and medicinal formulations [3]. The growing acceptance of peptides and modified peptides as drugs [4], strongly suggest that the pivotal role of tailormade AAs in the design of pharmaceuticals will continue to increase [5]. Asymmetric synthesis of AAs is a mature science offering a plethora of various approaches [6]. Over the last decade, preparation of tailor-made AAs via $\mathrm{Ni}(\mathrm{II})$

\begin{tabular}{ll}
\hline Received: & 10.05 .2021 \\
Revised: & 24.05 .2021 \\
Accepted: & 27.05 .2021 \\
Published online: & 30.06 .2021 \\
\hline
\end{tabular}

* Corresponding author. Tel.: +34-94-301-5177;

e-mail: vadym.soloshonok@ehu.es (V. A. Soloshonok);

hanj1@njfu.edu.cn (J. Han)

ORCID: 0000-0003-0681-4526 (V. A. Soloshonok);

0000-0002-3817-0764 (J. Han) complex intermediates (Scheme 1) has emerged as the most frequently used, methodologically dominant approach [7-8].

In this approach, chiral tridentate ligands 1 can be directly used in the reactions with racemic $\alpha$ - and $\beta$-AAs offering highly efficient deracemization, as well as $(S)$-to- $(R)$ interconversion protocols [9-10]. In a more general version, chiral ligands $\mathbf{1}$ are transformed to $\mathrm{Ni}(\mathrm{II})$ complexes of glycine Schiff bases $\mathbf{2}$ by the reaction with glycine and source of $\mathrm{Ni}$ (II) ions. Compounds $\mathbf{2}$ are widely used as chiral nucleophilic glycine equivalents in the alkyl halide alkylations [11], Michael [12], Mannich [13], aldol [14] addition reactions, as well as various multi-step transformations [15]. Products $\mathbf{3}$ can be conveniently disassembled to release target AAs $\mathbf{4}$ along with the recovery and reuse of chiral ligands $\mathbf{1}$. The overall process is economically and operationally attractive for large-scale asymmetric synthesis of tailor-made AAs [16]. Among the above-mentioned major pathways for homologation of the glycine moiety in complexes $\mathbf{2}$, aldol addition, due to its inherent reversibility, is the most challenging approach (Scheme 2) [7b]. In this methodological work, using a new 
type of chiral ligands, we designed an aldol-cyclization reaction cascade in attempt to investigate the effect of the formation of irreversible final products on the overall stereochemical outcome of this reaction sequence. The results reported here expand our knowledge of $\mathrm{Ni}(\mathrm{II})$ complexes aldol reactivity and highlight noticeably greater stereocontrolling properties of new type of chiral tridentate ligands.

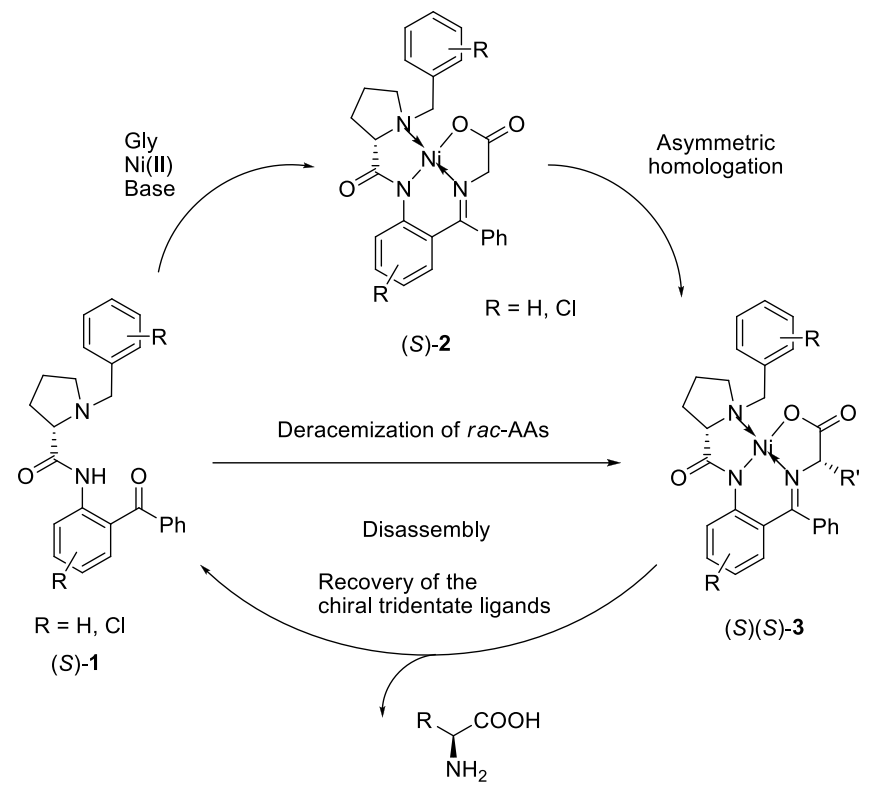

$(S)-4$

Scheme 1. Asymmetric synthesis of tailor-made amino acids via homologation of chiral glycine $(S)-\mathbf{1}$ Schiff base.

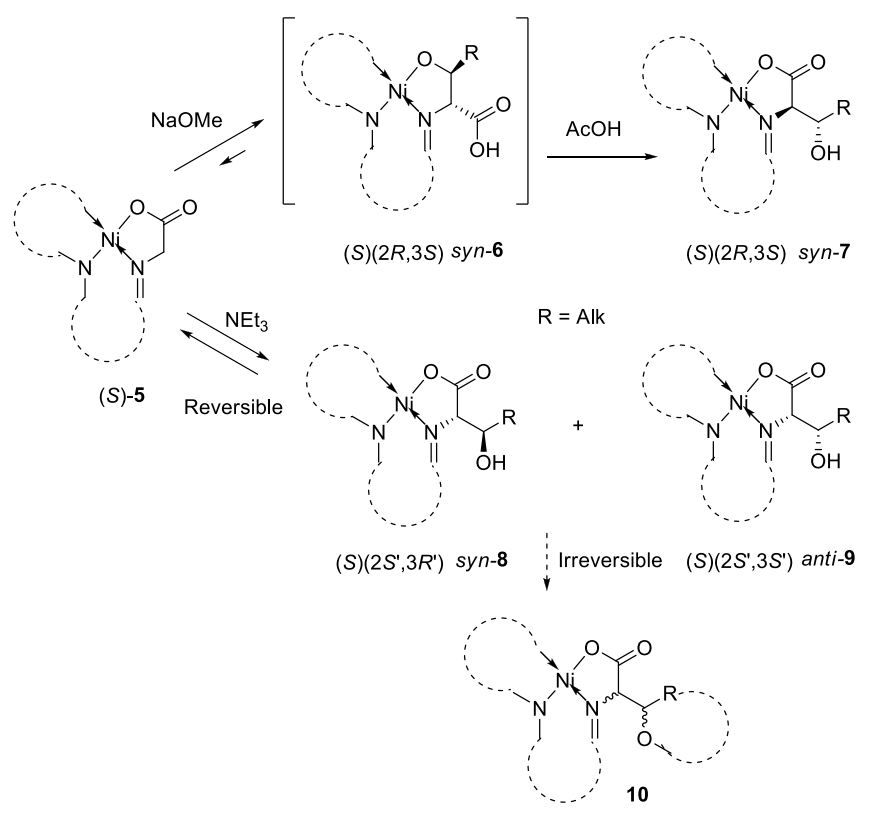

Scheme 2. General aspects of aldol addition reactions of $\mathrm{Ni}(\mathrm{II})$ complexes $\mathbf{5}$; formation of reversible syn-8 and anti-9, followed by cyclization to afford irreversible products $\mathbf{1 0}$.

From the standpoint of mechanism and stereochemical outcome, aldol addition reactions of $\mathrm{Ni}$ (II) complexes of glycine Schiff bases have two distinct patterns (Scheme 2) depending on the reaction conditions. The first type of reactivity is observed in the presence of strong bases, such as alkoxides [17] or DBU [18]. In this case the reactions<smiles>O=C1CN2C(c3ccccc3)=C(O1)c1cc(Cl)ccc1N1C(=O)[C@@H]3CCCN3[N+]21Cc1ccc(Cl)c(Cl)c1</smiles><smiles>COC(=O)c1ccccc1C=O</smiles><smiles>C1CC1</smiles>

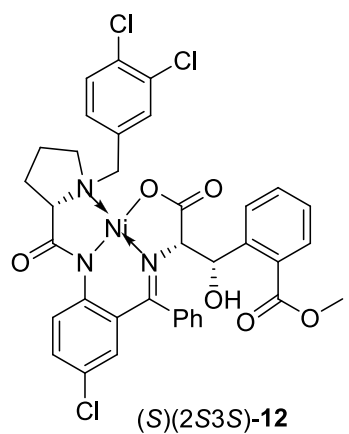

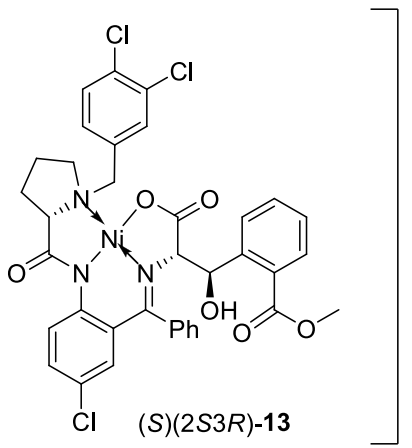

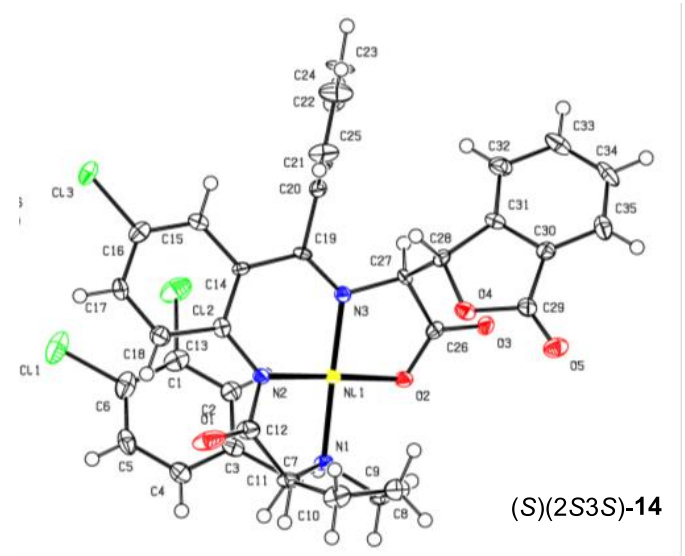

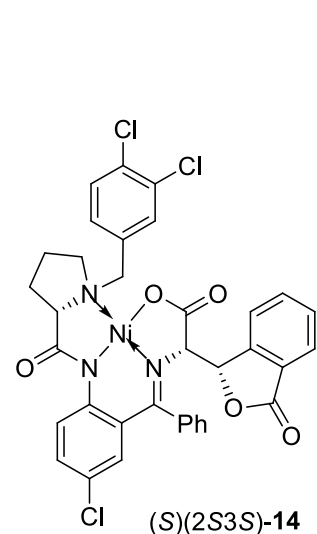

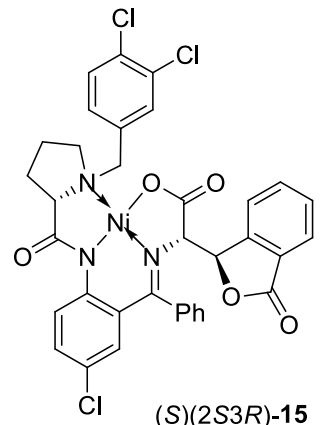

Scheme 3. Aldol addition-cyclization reaction cascade; major $(S)(2 S, 3 S)-\mathbf{1 4}$ and minor $(S)(2 S, 3 R)-\mathbf{1 5}$ products and crystallographic structure of major diastereomer $(S)(2 S, 3 S)-\mathbf{1 4}$. 
proceed with very high diastereoselectivity (> 90\% de) and are virtually irreversible due to the in situ formation of hydroxy group-coordinated species $\mathbf{6}$. Upon acidification of the reaction mixture, during work-up procedure, compounds 6 rearrange to a normal, carboxy group-coordinated complexes 7. In the second option, under weakly basic conditions, such as catalyzed by triethylamine, aldol addition reactions are distinctively reversible with the equilibrium strongly favoring the starting compounds [19].

Consequently, the reactions usually require over 10 -fold of the corresponding aldehyde to achieve a meaningful conversion of starting $\mathrm{Ni}$ (II) complexes 5. Furthermore, under these reaction conditions the thermodynamically controlled diastereoselectivity (syn-8 and anti-9) is quite low, ranging from 0 to $35 \%$ de. Considering these challenging inherent synthetic limitations, we were interested to know whether or not the stereochemical outcome can be improved when the aldol addition is followed by a transformation of reversible products syn-8 and anti-9 to irreversible derivatives $\mathbf{1 0}$.

\section{Results and Discussion}

We posited that such process can be realized in additioncyclization reaction cascade with in situ esterification of the key hydroxy group critical for the reverse aldol addition. As presented in Scheme 2, we selected methyl 2-formylbenzoate, possessing well-positioned aldehyde and ester functionalities for the desired addition-cyclization cascade. As for the starting glycine Schiff base Ni(II) complex, we selected recently developed compound $(S)$-11, derived from strategically chloro-substituted ligand [20]. Complex $(S)-\mathbf{1 1}$ has never been used in the aldol additions but showed superior stereocontrolling properties in the alkyl halide alkylation [21] and deracemization of unprotected $\alpha$ - [22] and $\beta$-AAs [10].

After a series of preliminary experiments, we established that 6 equivalents of triethylamine, as a base, and 2 equivalents of methyl 2-formylbenzoate can be suitably used as the starting point in the investigation. As presented in Table 1, screening the reaction solvents, such as dichloromethane (entry1), acetone (entry 2), acetonitrile (entry 3) and methanol (entry 4) at ambient temperature gave more or less similar results in term of diastereoselectivity affording $(S)(2 S, 3 S)$-complex $\mathbf{1 4}$ as the major reaction product. Diastereomers $(S)(2 S, 3 S)-\mathbf{1 4}$ and $(S)(2 S, 3 R)-\mathbf{1 5}$ were separated by column chromatography and fully characterized. Absolute configuration of major $(S)(2 S, 3 S)$-14 was established by single crystal X-ray analysis (Scheme 3 and SI). Absolute configuration of minor product $(S)(2 S, 3 R)$-15 was inferred based on its optical rotation $\left([\alpha]^{\mathrm{D}}=+1811.8\right)$, suggesting the $(2 S)$ stereochemistry and the $(3 R)$ by the deduction. No products with the $(2 R)$ absolute configuration, showing negative sign [19] of optical rotation, were found in the reaction mixture.

Considering entries $1-4$, we concluded that the reaction solvent has virtually no effect on the diastereoselectivity of this aldol additions providing products $(S)(2 S, 3 S)-\mathbf{1 4}$ and
Table 1. Optimization of reaction conditions ${ }^{\mathrm{a}}$.

\begin{tabular}{llllll}
\hline Entry & $\begin{array}{l}\text { Temp } \\
\left({ }^{\circ} \mathrm{C}\right)\end{array}$ & Solvent & $\begin{array}{l}\text { Ester } \\
\text { (equiv) }\end{array}$ & $\begin{array}{l}\text { Yield } \\
(\%)\end{array}$ & $\mathrm{Dr}^{\mathrm{c}}$ \\
\hline 1 & $\mathrm{rt}$ & $\mathrm{CH}_{2} \mathrm{Cl}_{2}$ & 2.0 & 21 & $32: 68$ \\
2 & $\mathrm{rt}$ & aceton & 2.0 & 16 & $28: 72$ \\
3 & $\mathrm{rt}$ & $\mathrm{MeCN}$ & 2.0 & 12 & $34: 66$ \\
4 & $\mathrm{rt}$ & $\mathrm{MeOH}$ & 2.0 & 53 & $37: 63$ \\
5 & -20 & $\mathrm{MeOH}$ & 2.0 & 66 & $64: 36$ \\
6 & 0 & $\mathrm{MeOH}$ & 2.0 & 76 & $54: 46$ \\
7 & 40 & $\mathrm{MeOH}$ & 2.0 & 58 & $25: 75$ \\
8 & 60 & $\mathrm{MeOH}$ & 2.0 & 50 & $22: 78$ \\
9 & 80 & $\mathrm{MeOH}$ & 2.0 & 45 & $19: 81$ \\
10 & 40 & $\mathrm{MeOH}$ & 3.0 & 77 & $13: 87$ \\
11 & 40 & $\mathrm{MeOH}$ & 5.0 & 93 & $20: 80$ \\
12 & 40 & $\mathrm{MeOH}$ & 10.0 & 93 & $26: 74$ \\
$13^{\mathrm{d}}$ & 40 & $\mathrm{MeOH}$ & 5.0 & 89 & $21: 79$ \\
$14^{\mathrm{d}}$ & 40 & $\mathrm{MeOH}$ & 2.0 & 79 & $22: 78$ \\
\hline
\end{tabular}

a Reaction conditions: $S$-CBPB $11(0.1 \mathrm{mmol})$, methyl 2-formylbenzoate, triethylamine ( 6 eq. $)$, solvent $(2.5 \mathrm{~mL}), 12 \mathrm{~h}$;

b Isolated yield;

${ }^{\mathrm{c}}$ Dr was determined by ${ }^{1} \mathrm{H}$ NMR;

${ }^{\mathrm{d}}$ Ethyl 2-formylbenzoate was used.

$(S)(2 S, 3 R)-15$ in ratios between 28:72 and 37:63. By contrast, the chemical yields ranged much more prominently depending the reaction solvent (entry 3 vs. 4), suggesting methanol as an optimal choice (entry 4). Thus using menthol as a solvent, we explored the effect of the reaction temperature on the diastereoselectivity. Quite unexpectedly, the reaction of glycine Schiff base Ni(II) complex $(S)$-2 with methyl 2-formylbenzoate conducted at $-20{ }^{\circ} \mathrm{C}$ gave rise to the reverse diastereomeric preferences affording $(S)(2 S, 3 R)-\mathbf{1 5}$ as a major product (entry 5). The same trend of the diastereoselectivity was still observed in the reaction conducted at $0{ }^{\circ} \mathrm{C}$, albeit the preference for diastereomer $(S)(2 S, 3 R)-\mathbf{1 5}$ was significantly reduced (entry $6)$. In sharp contrast the aldol addition performed at elevated temperature $\left(40^{\circ} \mathrm{C}\right.$, entry 7$)$. Further increase of the reaction temperature to $60{ }^{\circ} \mathrm{C}$ (entry 8 ) and $80{ }^{\circ} \mathrm{C}$ (entry 9) led to gradual increase in $(2 S, 3 S)$ diastereoselectivity recording the diastereomeric ratios of 22:78 and 19:81, respectively. On the other hand, the chemical yield followed the opposite trend gradually decreasing from $76 \%$ (entry 6) to $45 \%$ (entry 9 ).

Based on these results, we concluded that the optimal temperature for these aldol reactions should be $40{ }^{\circ} \mathrm{C}$ (entry 7 ). It should be noted that the reactions were quite sluggish and the starting materials were never fully converted to products $(S)(2 S, 3 S)-\mathbf{1 4}$ and $(S)(2 S, 3 R)-\mathbf{1 5}$ within the standard 12 hours of the reaction time. Accordingly, we conducted series of reactions using greater than 2 equivalents excess of methyl 2-formylbenzoate. As presented in entries 10-12 the increase in the aldehyde stoichiometry allowed for noticeable improvement of the chemical yield to a respected 93\% (entries 11, 12), suggesting 5 equivalents of the aldehyde as the optimal condition. Similar results were observed with application of 
ethyl 2-formylbenzoate in the place of methyl 2-formylbenzoate (entries 13, 14).

\section{Conclusions}

In conclusion, in this methodological work we explored the triethylamine-catalyzed addition-cyclization reaction cascade between a new type of chiral $\mathrm{Ni}$ (II) complex of glycine Schiff and methyl/ethyl 2-formylbenzoates. The results obtained point to the thermodynamically controlled diastereoselectivity due to the much greater reaction rates of the reversible aldol additions vs. irreversible cyclizations. Nevertheless, the observed temperature-dependent oscillation of the stereochemical preferences, giving preference for $(2 S, 3 R)$ at low and $(2 S, 3 S)$ at elevated temperatures, was quite unexpected. Furthermore, the achieved 4/1 level of diastereoselectivity with over $90 \%$ chemical yields suggest synthetic potential of these reactions clearly deserving more comprehensive and focused investigation.

\section{Experimental section}

All the commercial reagents including solvents were used directly without further purification. All the experiments were monitored by thin layer chromatography (TLC) with UV light. The TLC employed $0.25 \mathrm{~mm}$ silica gel coated on glass plates. Column chromatography was performed with silica gel 60 (300-400 mesh). NMR spectra were recorded on Bruker $600 \mathrm{MHz}$ spectrometers. Mass spectra (MS) were measured on Shimadzu LCMS-2020 with an etrospray ionization (ESI) probe operating in positive mode. Values of optical rotation were measured on Automatic Polarimeter SGW-531.

General procedures for the reaction between methyl 2-formylbenzoate and (S)-11

Into a $10 \mathrm{~mL}$ vial were taken $(S)-\mathbf{1 1}(0.1 \mathrm{mmol})$, methyl 2-formylbenzoate (5 equiv), triethylamine (6 equiv), methanol $(2.5 \mathrm{~mL})$. The mixture was stirred at $40{ }^{\circ} \mathrm{C}$ for $12 \mathrm{~h}$. Then the reaction was concentrated in vacuo. The residue was purified by column chromatography using DCM/EtOAc $(1: 1, \mathrm{v} / \mathrm{v})$ as eluent to afford the desired product.

Compound $(S)(2 S 3 S)-14$ : red solid, mp $168-169^{\circ} \mathrm{C}$; $[\alpha]_{\mathrm{D}}{ }^{25}+2514.4$ (c $\left.0.09, \mathrm{MeOH}\right) .{ }^{1} \mathrm{H}$ NMR $(600 \mathrm{MHz}$, $\left.\mathrm{CDCl}_{3}\right) \delta 8.99(\mathrm{~d}, J 2.04 \mathrm{~Hz}, 1 \mathrm{H}), 8.14(\mathrm{~d}, J 9.24 \mathrm{~Hz}, 1 \mathrm{H})$, 7.88-7.86 (m, 1H), 7.80-7.79 (m, 1H), 7.77-7.74 (m, 1H), 7.72-7.69 (m, 1H), 7.60-7.57 (m, 1H), 7.54-7.48 (m, 2H), 7.45-7.43 (m, 1H), $7.41(\mathrm{~d}, J 8.16 \mathrm{~Hz}, 1 \mathrm{H}), 7.19-7.17(\mathrm{~m}$, 1H), 7.10-7.08 (m, 1H), 6.73 (d, J $2.58 \mathrm{~Hz}, 1 \mathrm{H}), 6.40-6.39$ $(\mathrm{m}, 1 \mathrm{H}), 5.29(\mathrm{~s}, 1 \mathrm{H}), 4.51(\mathrm{~d}, J 1.74 \mathrm{~Hz}, 1 \mathrm{H}), 4.27(\mathrm{~d}$, $J 12.66 \mathrm{~Hz}, 1 \mathrm{H}), 4.19-4.11(\mathrm{~m}, 1 \mathrm{H}), 3.61-3.58(\mathrm{~m}, 1 \mathrm{H})$, $3.41-3.38(\mathrm{~m}, 1 \mathrm{H}), 3.21(\mathrm{~d}, J 12.72 \mathrm{~Hz}, 1 \mathrm{H}), 2.94-2.88(\mathrm{~m}$, $1 \mathrm{H}), 2.68-2.60(\mathrm{~m}, 1 \mathrm{H}), 2.31-2.27(\mathrm{~m}, 1 \mathrm{H}), 2.12-2.06(\mathrm{~m}$, 1H). ${ }^{13} \mathrm{C}\left\{{ }^{1} \mathrm{H}\right\}$ NMR $\left(150 \mathrm{MHz}, \mathrm{CDCl}_{3}\right) \delta 180.5,172.3$, $171.4,169.3,145.2,141.5,135.2,134.3,133.8,133.4$, $133.2,133.1,132.9,132.1,131.0,130.7,130.1,129.9$,
$129.8,127.4,127.1,127.0,125.9,125.7,125.5,124.7$, 121.6, 81.6, 72.8, 71.7, 63.0, 58.9, 31.3, 29.9, 23.2. MS (ESI) $\mathrm{m} / z$ Calcd. for $\mathrm{C}_{35} \mathrm{H}_{27} \mathrm{Cl}_{3} \mathrm{~N}_{3} \mathrm{NiO}_{5}{ }^{+}[\mathrm{M}+\mathrm{H}]^{+} 732.0$. Found 732.0.

Compound $(S)(2 S 3 R)-15$ : red solid, mp $142-144{ }^{\circ} \mathrm{C}$; $[\alpha]_{\mathrm{D}}{ }^{25}+1811.8(\mathrm{c} 0.06, \mathrm{MeOH}) .{ }^{1} \mathrm{H} \mathrm{NMR}(600 \mathrm{MHz}$, $\left.\mathrm{CDCl}_{3}\right) \delta 9.00(\mathrm{~d}, J 2.04 \mathrm{~Hz}, 1 \mathrm{H}), 8.18(\mathrm{~d}, J 9.36 \mathrm{~Hz}, 1 \mathrm{H})$, 7.82-7.80 (m, 1H), 7.75-7.73 (m, 1H), 7.50-7.42 (m, 4H), $7.32(\mathrm{~d}, J 8.22 \mathrm{~Hz}, 1 \mathrm{H}), 7.27-7.25(\mathrm{~m}, 1 \mathrm{H}), 7.15-7.12(\mathrm{~m}$, $1 \mathrm{H}), 7.07-7.05(\mathrm{~m}, 1 \mathrm{H}), 6.92-6.91(\mathrm{~m}, 1 \mathrm{H}), 6.41(\mathrm{~d}, J 2.58$ $\mathrm{Hz}, 1 \mathrm{H}), 6.06$ (d, J $3.84 \mathrm{~Hz}, 1 \mathrm{H}), 6.00-5.98$ (m, 1H), 4.50 $(\mathrm{d}, J 3.9 \mathrm{~Hz}, 1 \mathrm{H}), 4.29(\mathrm{~d}, J 12.6 \mathrm{~Hz}, 1 \mathrm{H}), 4.11-4.05(\mathrm{~m}$, $1 \mathrm{H}), 3.58-3.56(\mathrm{~m}, 1 \mathrm{H}), 3.40-3.37(\mathrm{~m}, 1 \mathrm{H}), 3.18-3.14(\mathrm{~m}$, $2 \mathrm{H}), 2.73-2.66(\mathrm{~m}, 1 \mathrm{H}), 2.29-2.22(\mathrm{~m}, 1 \mathrm{H}), 2.16-2.11(\mathrm{~m}$, 1H). ${ }^{13} \mathrm{C}\left\{{ }^{1} \mathrm{H}\right\}$ NMR $\left(150 \mathrm{MHz}, \mathrm{CDCl}_{3}\right) \delta 179.8,175.4$, $172.4,168.6,144.9,141.7,135.2,134.5,133.6,133.4$, $133.3,132.9,132.8,132.3,131.1,130.2,129.8,129.7$, $129.6,129.2,128.8,127.2,127.1,125.9,125.8,125.4$, 123.5, 123.4, 80.5, 72.1, 71.8, 63.3, 58.9, 30.6, 29.7, 23.3. MS (ESI) $\mathrm{m} / z$ Calcd. for $\mathrm{C}_{35} \mathrm{H}_{27} \mathrm{Cl}_{3} \mathrm{~N}_{3} \mathrm{NiO}_{5}{ }^{+}[\mathrm{M}+\mathrm{H}]^{+} 732.0$. Found 732.7 .

\section{Notes}

Acknowledgments and finances. This research was funded by the National Natural Science Foundation of China (No. 21761132021) and IKERBASQUE, Basque Foundation for Science (for Soloshonok).

\section{The authors declare no conflict of interest.}

Author contributions. Yupiao Zou, Zizhen Yin: Synthesis of compounds, Investigation, Formal analysis, writing experimental section. Haibo Mei, Hiroyuki Konno: Investigation, Formal analysis, writing most of the manuscript. Hiroki Moriwaki, Vadim A. Soloshonok and Jianlin Han: Conceptualization, Supervision, Writing review \& editing. Zizhen Yin: X-ray analysis.

\section{Supporting information}

The characterization data, NMR spectra and single crystal for 14.

\section{References}

1. For the definition of "tailor-made amino acids", see: Soloshonok, V. A.; Cai, C.; Hruby, V. J.; Meervelt, L. V. Asymmetric synthesis of novel highly sterically constrained (2S,3S)-3-methyl-3trifluoromethyl- and (2S,3S,4R)-3-trifluoromethyl-4-methylpyroglutamic acids. Tetrahedron 1999, 55, 12045-12058.

2. a) Zhou, Y.; Wang, J.; Gu, Z.; Wang, S.; Zhu, W.; Aceña, J. L.; Soloshonok, V. A.; Izawa, K.; Liu, H. Next Generation of FluorineContaining Pharmaceuticals, Compounds Currently in Phase II-III Clinical Trials of Major Pharmaceutical Companies: New Structural Trends and Therapeutic Areas. Chem. Rev. 2016, 116, 422-518; b) Zhu, W.; Wang, J.; Wang, S.; Gu, Z.; Aceña, J.L.; Izawa, K.; Liu, H.; Soloshonok, V. A. Recent advances in the trifluoromethylation methodology and new CF3-containing drugs. J. Fluorine Chem. 2014, 167, 37-54; c) Mei, H.; Han, J.; Fustero, S.; Medio-Simon, M.; Sedgwick, D. M.; Santi, C.; Ruzziconi, R.; Soloshonok, V. A. Fluorine-containing drugs approved by the FDA in 2018. Chem. Eur. J. 2019, 25, 11797-11819; d) Liu, J.; Li, Z.; Mei, H.; Soloshonok, V. 
A.; Han, J. Detrifluoroacetylative in Situ Generated Cyclic Fluorinated Enolates for the Preparation of Compounds Featuring a C-F Stereogenic Center. ACS Omega 2019, 4, 19505-19512; e) Zhu, Y.; Han, J.; Wang, J.; Shibata, N.; Sodeoka, M.; Soloshonok, V. A.; Coelho, J. A. S.; Toste, F. D. Modern Approaches for Asymmetric Construction of Carbon-Fluorine Quaternary Stereogenic Centers: Synthetic Challenges and Pharmaceutical Needs. Chem. Rev. 2018, 118, 3887-3964.

3. a) Wang, J.; Sánchez-Roselló, M.; Aceña, J. L.; del Pozo, C.; Sorochinsky, A. E.; Fustero, S.; Soloshonok, V. A.; Liu, H. Fluorine in Pharmaceutical Industry: Fluorine-Containing Drugs Introduced to the Market in the Last Decade (2001-2011). Chem. Rev. 2014, 114, 2432-2506; b) Meanwell, N. A. Fluorine and Fluorinated Motifs in the Design and Application of Bioisosteres for Drug Design. J. Med. Chem. 2018, 61, 5822-5880; c) Ilardi, E. A.; Vitaku, E.; Njardarson, J. T. Data-Mining for Sulfur and Fluorine: An Evaluation of Pharmaceuticals To Reveal Opportunities for Drug Design and Discovery. $J$. Med. Chem. 2014, 57, 2832-2842; d) Mei, H.; Han, J.; Klika, K. D.; Izawa, K.; Sato, T.; Meanwell, N. A.; Soloshonok, V. A. Applications of fluorine-containing amino acids for drug design. Eur. J. Med. Chem. 2020, 186, 111826.

4. a) Soloshonok, V. A.; Izawa, K. (Eds.) Asymmetric Synthesis and Application of $\alpha$-Amino Acids. ACS Symposium Series 1009, Oxford University Press: Oxford, UK, 2009; b) Henninot, A.; Collins, J. C.; Nuss, J. M. The Current State of Peptide Drug Discovery: Back to the Future? J. Med. Chem. 2018, 61, 1382-1414; c) Blaskovich, M. A. T. Unusual Amino Acids in Medicinal Chemistry. J. Med. Chem. 2016, 59, 10807-10836; d) Soloshonok, V. A.; Sorochinsky, A. E. Practical Methods for the Synthesis of Symmetrically $\alpha, \alpha$-Disubstituted $\alpha$-Amino Acids. Synthesis 2010, 2319-2344.

5. a) Ma, J. S. Unnatural amino acids in drug discovery. Chim. Oggi 2003, 21, 65-68; b) Hodgson, D. R. W.; Sanderson, J. M. The synthesis of peptides and proteins containing non-natural amino acids. Chem. Soc. Rev. 2004, 33, 422-430; c) Sato, T.; Izawa, K.; Aceña, J. L.; Liu, H.; Soloshonok, V. A. Tailor-Made $\alpha$-Amino Acids in the Pharmaceutical Industry: Synthetic Approaches to (1R,2S)-1-Amino2-vinylcyclopropane-1-carboxylic Acid (Vinyl-ACCA). Eur. J. Org. Chem. 2016, 2757-2774; d) Wang, S.; Wang, Y.; Wang, J.; Sato, T.; Izawa, K.; Soloshonok, V. A.; Liu, H. The Second-generation of Highly Potent Hepatitis C Virus (HCV) NS3/4A Protease Inhibitors: Evolutionary Design Based on Tailor-made Amino Acids, Synthesis and Major Features of Bio-activity. Curr. Pharm. Des. 2017, 23, 4493-4554.

6. Reviews on amino acids, see: a) Sorochinsky, A. E.; Soloshonok, V. A. Asymmetric synthesis of fluorine-containing amines, amino alcohols, $\alpha$-and $\beta$-amino acids mediated by chiral sulfinyl group. $J$. Fluorine Chem. 2010, 131, 127-139; b) Aceña, J. L.; Sorochinsky, A. E.; Soloshonok, V. A. Recent advances in the asymmetric synthesis of $\alpha$-(trifluoromethyl)-containing $\alpha$-amino acids. Synthesis 2012, 44, 1591-1602; c) Turcheniuk, K. V.; Kukhar, V. P.; Roeschenthaler, G.V.; Aceña, J. L.; Soloshonok, V. A.; Sorochinsky, A. E. Recent advances in the synthesis of fluorinated aminophosphonates and aminophosphonic acids. $R S C A d v$. 2013, 3, 6693-6716; d) Kukhar, V. P.; Sorochinsky, A. E.; Soloshonok, V. A. Practical synthesis of fluorine-containing $\alpha$ - and $\beta$-amino acids: recipes from Kiev, Ukraine. Future Med. Chem. 2009, 1, 793-819; e) Soloshonok, V. A. Highly diastereoselective michael addition reactions between nucleophilic glycine equivalents and $\beta$-substituted- $\alpha, \beta$-unsaturated carboxylic acid derivatives a general approach to the stereochemically defined and sterically $\chi$-constrained $\alpha$-amino acids. Curr. Org. Chem. 2002, 6, 341-364; f) Mikami, K.; Fustero, S.; Sánchez-Roselló, M.; Aceña, J. L.; Soloshonok, V. A.; Sorochinsky, A. E. Synthesis of fluorinated $\beta$-amino acids. Synthesis 2011, 30453079; g) Soloshonok, V. A.; Ohkura, H.; Yasumoto, M. Operationally convenient asymmetric synthesis of $(S)$ - and $(R)-3$ amino-4,4,4-trifluorobutanoic acid: Part II. Enantioselective biomimetic transamination of 4,4,4-trifluoro-3-oxo-N-[(R)-1phenylethyl]butanamide. J. Fluorine Chem. 2006, 127, 930-935; h) Han, J.; Sorochinsky, A. E.; Ono, T.; Soloshonok, V. A. Biomimetic transamination-a metal-free alternative to the reductive amination. Application for generalized preparation of fluorinecontaining amines and amino acids. Curr. Org. Synth. 2011, 8, 281294; i) Wzorek, A.; Sato, A.; Drabowicz, J.; Soloshonok, V. A.; Klika, K. D. Remarkable magnitude of the self-disproportionation of enantiomers (SDE) via achiral chromatography: application to the practical-scale enantiopurification of $\beta$-amino acid esters. Amino Acids 2016, 48, 605-613; j) Han, J.; Romoff, T. T.; Moriwaki, H.; Konno, H.; Soloshonok, V. A. Development of Hamari ligands for practical asymmetric synthesis of tailor-made amino acids. ACS Omega 2019, 4, 18942-18947; k) Han, J.; Wzorek, A.; Kwiatkowska, M.; Soloshonok, V. A.; Klika, K. D. The self-disproportionation of enantiomers (SDE) of amino acids and their derivatives. Amino Acids 2019, 51, 865-889.

7. For reviews, see: a) Sorochinsky, A. E.; Aceña, J. L.; Moriwaki, H.; Sato, T.; Soloshonok, V. A. Asymmetric synthesis of $\alpha$-amino acids via homologation of $\mathrm{Ni}$ (II) complexes of glycine Schiff bases. Amino Acids 2013, 45, 691-718; b) Sorochinsky, A. E.; Aceña, J. L.; Moriwaki, H.; Sato, T.; Soloshonok, V. A. Asymmetric synthesis of $\alpha$-amino acids via homologation of $\mathrm{Ni}$ (II) complexes of glycine Schiff bases. Part 2: Aldol, Mannich addition reactions, deracemization and $(S)$ to $(R)$ interconversion of $\alpha$-amino acids. Amino Acids 2013, 45, 1017-1033; c) Aceña, J. L.; Sorochinsky, A. E.; Moriwaki, H.; Sato, T.; Soloshonok, V. A. Synthesis of fluorinecontaining $\alpha$-amino acids in enantiomerically pure form via homologation of $\mathrm{Ni}$ (II) complexes of glycine and alanine Schiff bases. J. Fluorine Chem. 2013, 155, 21-38; d) Aceña, J. L.; Sorochinsky, A. E.; Soloshonok, V. A. Asymmetric synthesis of $\alpha$-amino acids via homologation of $\mathrm{Ni}$ (II) complexes of glycine Schiff bases. Part 3: Michael addition reactions and miscellaneous transformations. Amino Acids 2014, 46, 2047-2073; e) Wang, Y.; Song, X.; Wang, J.; Moriwaki, H.; Soloshonok, V. A.; Liu, H. Recent approaches for asymmetric synthesis of $\alpha$-amino acids via homologation of $\mathrm{Ni}$ (II) complexes. Amino Acids 2017, 49, 1487 1520; f) Mei, H.; Jean, M.; Albalat, M.; Vanthuyne, N.; Roussel, C.; Moriwaki, H.; Yin, Z.; Han, J.; Soloshonok, V. A. Effect of substituents on the configurational stability of the stereogenic nitrogen in metal (II) complexes of $\alpha$-amino acid Schiff bases. Chirality 2019, 31, 401-409.

8. For recent paper, see: a) Bergagnini, M.; Fukushi, K.; Han, J.; Shibata, N.; Roussel, C.; Ellis, T. K.; Aceña, J. L.; Soloshonok, V. A. $\mathrm{NH}$-type of chiral Ni (II) complexes of glycine Schiff base: design, structural evaluation, reactivity and synthetic applications. Org. Biomol. Chem. 2014, 12, 1278-1291; b) Wang, S.; Zhou, S.; Wang, J.; Nian, Y.; Kawashima, A.; Moriwaki, H.; Aceña, J. L.; Soloshonok, V. A.; Liu, H. Chemical dynamic thermodynamic resolution and $\mathrm{S} / \mathrm{R}$ interconversion of unprotected unnatural tailormade $\alpha$-amino acids. J. Org. Chem. 2015, 80, 9817-9830; c) Li, J.; Zhou, S.; Wang, J.; Kawashima, A.; Moriwaki, H.; Soloshonok, V. A.; Liu, H. Asymmetric Synthesis of Aromatic and Heteroaromatic $\alpha$-Amino Acids Using a Recyclable Axially Chiral Ligand. Eur. J. Org. Chem. 2016, 999-1006; d) Takeda, R.; Kawamura, A.; Kawashima, A.; Sato, T.; Moriwaki, H.; Izawa, K.; Abe, H.; Soloshonok, V. A. Second-order asymmetric transformation and its application for the practical synthesis of $\alpha$-amino acids. Org. Biomol. Chem. 2018, 16, 4968-4972.

9. a) Soloshonok, V. A.; Ellis, T. K.; Ueki, H.; Ono, T. Resolution/deracemization of chiral $\alpha$-amino acids using resolving reagents with flexible stereogenic centers. J. Am. Chem. Soc. 2009 , 131, 7208-7209; b) Takeda, R.; Kawamura, A.; Kawashima, A.; Sato, T.; Moriwaki, H.; Izawa, K.; Akaji, K.; Wang, S.; Liu, H.; Aceña, J. L.; Soloshonok, V. A. Chemical dynamic kinetic resolution and $\mathrm{S} / \mathrm{R}$ interconversion of unprotected $\alpha$-amino acids. Angew. Chem. Int. Ed. 2014, 53, 12214-12217; c) Sorochinsky, A. E.; Ueki, H.; Aceña, J. L.; Ellis, T. K.; Moriwaki, H.; Soloshonok, V. A. Chemical approach for interconversion of $(S)$-and $(R)$ - $\alpha$-amino acids. Org. Biomol. Chem. 2013, 11, 4503-4507.

10. Zhou, S.; Wang, J.; Chen, X.; Aceña, J. L.; Soloshonok, V. A.; Liu, $\mathrm{H}$. Chemical kinetic resolution of unprotected $\beta$-substituted $\beta$-amino acids using recyclable chiral ligands. Angew. Chem. Int. Ed. 2014, 53, 7883-7886.

11. a) Taylor, S. M.; Yamada, T.; Ueki, H.; Soloshonok, V. A. Asymmetric synthesis of enantiomerically pure 4-aminoglutamic acids via methylenedimerization of chiral glycine equivalents with dichloromethane under operationally convenient conditions. Tet. Lett. 2004, 45, 9159-9162; b) Ellis, T. K.; Hochla, V. M.; Soloshonok, V. A. Efficient synthesis of 2-aminoindane-2-carboxylic acid via dialkylation of nucleophilic glycine equivalent. J. Org. Chem. 2003, 68, 4973-4976; c) Wang, J.; Lin, D.; Zhou, S.; Soloshonok, V. A.; Liu, H. Asymmetric synthesis of sterically and electronically demanding linear $\omega$-trifluoromethyl containing amino acids via alkylation of chiral equivalents of nucleophilic glycine and alanine. $J$. Org. Chem. 2011, 76, 684-687.

12. a) Yamada, T.; Okada, T.; Sakaguchi, K.; Ohfune, Y.; Ueki, H.; Soloshonok, V. A. Efficient asymmetric synthesis of novel 4-substituted and configurationally stable analogues of thalidomide. Org. Lett. 2006, 8, 5625-5628; b) Yamada, T.; Sakaguchi, K.; Shinada, T.; Ohfune, Y.; Soloshonok, V. A. Efficient asymmetric 
synthesis of the functionalized pyroglutamate core unit common to oxazolomycin and neooxazolomycin using Michael reaction of nucleophilic glycine Schiff base with $\alpha, \beta$-disubstituted acrylate Tetrahedron: Asymmetry 2008, 19, 2789-2795; c) Soloshonok, V. A.; Cai, C.; Hruby, V. J. (S)-or (R)-3-(E-Enoyl)-4-phenyl-1, 3-oxazolidin-2-ones: ideal Michael acceptors to afford a virtually complete control of simple and face diastereoselectivity in addition reactions with glycine derivatives. Org. Lett. 2000, 2, 747-750.

13. a) Kawamura, A.; Moriwaki, H.; Röschenthaler, G.-V.; Kawada, K.; Aceña, J. L.; Soloshonok, V. A. Synthesis of $(2 S, 3 S)-\beta-$ (trifluoromethyl)- $\alpha, \beta$-diamino acid by Mannich addition of glycine Schiff base $\mathrm{Ni}$ (II) complexes to $N$-tert-butylsulfinyl-3,3,3trifluoroacetaldimine. J. Fluorine Chem. 2015, 171, 67-72; b) Soloshonok, V. A.; Avilov, D. V.; Kukhar, V. P.; Meervelt, L. V.; Mischenko, N. Highly diastereoselective aza-aldol reactions of a chiral $\mathrm{Ni}$ (II) complex of glycine with imines. An efficient asymmetric approach to 3-perfluoroalkyl-2,3-diamino acids. Tet. Lett. 1997, 38, 4671-4674.

14. a) Jörres, M.; Aceña, J. L.; Soloshonok, V. A.; Bolm, C. Asymmetric carbon-carbon bond formation under solventless conditions in ball mills. ChemCatChem 2015, 7, 1265-1269; b) Jörres, M.; Chen, X.; Aceña, J. L.; Merkens, C.; Bolm, C.; Liu, H.; Soloshonok, V. A. Asymmetric synthesis of $\alpha$-amino acids under operationally convenient conditions. Adv. Synth. Catal. 2014, 356, 2203-2208.

15. a) Kawashima, A.; Shu, S.; Takeda, R.; Kawamura, A.; Sato, T.; Moriwaki, H.; Wang, J.; Izawa, K.; Aceña, J. L.; Soloshonok, V. A.; Liu, H. Advanced asymmetric synthesis of $(1 R, 2 S)$-1-amino-2vinylcyclopropanecarboxylic acid by alkylation/cyclization of newly designed axially chiral Ni (II) complex of glycine Schiff base. Amino Acids 2016, 48, 973-986; b) Kawashima, A.; Xie, C.; Mei, H.; Takeda, R.; Kawamura, A.; Sato, T.; Moriwaki, H.; Izawa, K.; Han, J.; Aceña, J. L.; Soloshonok, V. A. Asymmetric synthesis of $(1 R$, $2 S)$-1-amino-2-vinylcyclopropanecarboxylic acid by sequential SN 2 SN 2' dialkylation of $(R)-N$-(benzyl) proline-derived glycine Schiff base Ni (II) complex. RSC Adv. 2015, 5, 1051-1058.

16. Large-scale synthesis, see: a) Yin, Z.; Moriwaki, H.; Abe, H.; Miwa, T.; Han, J.; Soloshonok, V. A. Large-scale asymmetric synthesis of Fmoc-(S)-2-amino-6, 6, 6-trifluorohexanoic acid. ChemistryOpen 2019, 8, 701-704; b) Mei, H.; Yin, Z.; Miwa, T.; Moriwaki, H.; Abe, H.; Han, J.; Soloshonok, V. A. Convenient asymmetric synthesis of Fmoc- $(S)-6,6,6$-trifluoro-Norleucine. Symmetry 2019, 11, 578, c) Mei, H.; Hiramatsu, T.; Takeda, R.; Moriwaki, H.; Abe, H.; Han, J.; Soloshonok. V. A. Expedient asymmetric synthesis of $(S)$-2Amino-4, 4, 4-trifluorobutanoic acid via alkylation of chiral nucleophilic glycine equivalent. Org. Process Res. Dev. 2019, 23, 629-634; d) Han, J.; Takeda, R.; Liu, X.; Konno, H.; Abe, H.; Hiramatsu, T.; Moriwaki, H.; Soloshonok, V. A. Preparative Method for asymmetric synthesis of $(s)$-2-amino-4, 4, 4-trifluorobutanoic acid. Molecules 2019, 24, 4521.

17. a) Soloshonok, V. A.; Kukhar, V. P.; Galushko, S. V.; Svistunova, N. Y.; Avilov, D. V.; Kuzmina, N. A.; Raevski, N. I.; Struchkov, Y. T.; Pisarevsky, A. P.; Belokon, Y. N. General method for the synthesis of enantiomerically pure $\beta$-hydroxy- $\alpha$-amino acids, containing fluorine atoms in the side chains. Case of stereochemical distinction between methyl and trifluoromethyl groups. X-Ray crystal and molecular structure of the nickel (II) complex of $(2 S, 3 S)-2$ (trifluoromethyl) threonine. J. Chem. Soc. Perkin Trans 1 1993, 3143-3155; b) Soloshonok, V. A.; Avilov, D. V.; Kukhar, V. P. Highly diastereoselective asymmetric aldol reactions of chiral $\mathrm{Ni}$ (II)-complex of glycine with alkyl trifluoromethyl ketones. Tetrahedron: Asymmetry 1996, 7, 1547-1550; c) Soloshonok, V. A.; Avilov, D. V.; Kukhar, V. P. Asymmetric aldol reactions of trifluoromethyl ketones with a chiral Ni (II) complex of glycine: stereocontrolling effect of the trifluoromethyl group. Tetrahedron 1996, 52, 12433-12442.

18. a) Li, T.; Zhou, S.; Wang, J.; Aceña, J. L.; Soloshonok, V. A.; Liu, H. Asymmetric synthesis of $\alpha$-(1-oxoisoindolin-3-yl) glycine: Synthetic and mechanistic challenges. Chem. Commun. 2015, 51, 1624-1626; b) Li, T.; Zhou, S.; Wang, J.; Aceña, J. L.; Soloshonok, V. A.; Liu, H. Asymmetric synthesis of $(2 \mathrm{~S}, 3 \mathrm{~S})-\alpha-(1-$ oxoisoindolin-3-yl) glycines under low-basicity "kinetic" control. $J$. Org. Chem. 2015, 80, 11275-11280.

19. Soloshonok, V. A.; Avilov, D. V.; Kukhar, V. P.; Tararov, V. I., et al. Asymmetric aldol reactions of chiral Ni (II)-complex of glycine with aliphatic aldehydes. Stereodivergent synthesis of syn- $(2 S)$-and syn(2R)- $\beta$-alkylserines. Tetrahedron: Asymmetry 1995, 6, 1741-1756.

20. a) Nian, Y.; Wang, J.; Moriwaki, H.; Soloshonok, V. A.; Liu, H. Analysis of crystallographic structures of $\mathrm{Ni}$ (ii) complexes of $\alpha$-amino acid Schiff bases: elucidation of the substituent effect on stereochemical preferences. Dalton Trans. 2017, 46, 4191-4198; b) Romoff, T. T.; Palmer, A. B.; Mansour, N.; Creighton, C. J.; Miwa, T.; Ejima, Y.; Moriwaki, H.; Soloshonok, V. A. Scale-up synthesis of $(R)$-and $(S)$-N-(2-Benzoyl-4-chlorophenyl)-1-(3,4dichlorobenzyl) pyrrolidine-2-carboxamide hydrochloride, a versatile reagent for the preparation of tailor-made $\alpha$-and $\beta$-amino acids in an enantiomerically pure form. Org. Process Res. Dev. 2017, 21, 732739 .

21. a) Takeda, R.; Abe, H.; Shibata, N.; Moriwaki, H.; Izawa, K.; Soloshonok, V. A. Asymmetric synthesis of $\alpha$-deuterated $\alpha$-amino acids. Org. Biomol. Chem. 2017, 15, 6978-6983; b) Yamamoto, J.; Kawashima, A.; Kawamura, A.; Abe, H.; Moriwaki, H.; Shibata, N.; Soloshonok, V. A. Operationally Convenient and Scalable Asymmetric Synthesis of (2S)-and (2R)- $\alpha$-(Methyl) cysteine Derivatives through Alkylation of Chiral Alanine Schiff Base NiII Complexes. Eur. J. Org. Chem. 2017, 1931-1939.

22. a) Nian, Y.; Wang, J.; Zhou, S.; Wang, S.; Moriwaki, H.; Kawashima, A.; Soloshonok, V. A.; Liu, H. Recyclable ligands for the non-enzymatic dynamic kinetic resolution of challenging $\alpha$ amino acids. Angew. Chem. Int. Ed. 2015, 54, 12918-12922; b) Nian, Y.; Wang, J.; Zhou, S.; Dai, W.; Wang, S.; Moriwaki, H.; Kawashima, A.; Soloshonok, V. A.; Liu, H. Purely chemical approach for preparation of $\mathrm{D}$ - $\alpha$-amino acids via $(S)$-to- $(R)$ interconversion of unprotected tailor-made $\alpha$-amino acids. J. Org. Chem. 2016, 81, 3501-3508; c) Mei, H.; Han, J.; Takeda, R.; Sakamoto, T.; Miwa, T.; Minamitsuji, Y.; Moriwaki, H.; Abe, H.; Soloshonok, V. A. Practical method for preparation of $(S)$-2-Amino5,5,5-trifluoropentanoic acid via dynamic kinetic resolution. ACS Omega 2019, 4, 11844-11851. 


\title{
Каскадні реакції альдольного приєднання та циклізації на основі хірального комплексу $\mathrm{Ni}(\mathrm{II})$ основи Шифа гліцину
}

\author{
Ю. Чжоу ${ }^{1}$ Ц . Їнь ${ }^{1}$, Х. Мей${ }^{1}$ Х. Конно ${ }^{2}$ Х. Морівакі ${ }^{3}$, В. А. Солошонок ${ }^{4,5 *}$, Ц. Хань ${ }^{1 *}$ \\ ${ }^{1}$ Нанкінський лісотехнічний університет, вул. Лонпан роуд, 159, Нанкін, 210037, КНР \\ ${ }^{2}$ Вища школа науки і технології, Ямагатський університет, Йонезава, Ямагата, 992-8510, Японія \\ ${ }^{3}$ Гамарі Кемікалс Лто., 1-19-40, Нанкокіта, Суміное-ку, Осака, 559-0034, Японія \\ ${ }^{4}$ Університет Краӥни Басків, вул. Пасео Мануель Лардізабаля, 3, Сан-Себастьян, 20018, Іспанія \\ ${ }^{5}$ ІКЕРБАСК, Баскський фонд науки, вул. Марії Діас де Аро, Більбао, 48013, Іспанія
}

Резюме: На базі хірального комплексу Ni(II) основи Шифа гліцину нового типу було розроблено каскадні реакції приєднання-циклізації з метою вивчення аспектів кінетичного/термодинамічного утворення відповідних $(S)(2 S, 3 S) /(S)(2 S, 3 R)$ діастереомерів. Було знайдено, що утворені лактони в значній мірі є продуктами термодинамічно контрольованої діастереоселективності завдяки значному внеску зворотньої реакції альдольного приєднання порівняно із подальшою циклізацією. Досить несподіваним виявився факт температурної залежності стереохімічних співвідношень продуктів реакції: при низькій температурі утворювався переважно $(2 S, 3 R)$ діастереомер, у той час як при підвіщеній - $(2 S, 3 S)$. Спостережувана діастереоселективність становила 4/1 $(S)(2 S, 3 S) /(S)(2 S, 3 R)$, що є значно кращим показником порівняно із попередніми даними (1.7/1). Подібний рівень діастереоселективності, а також сумарний вихід продуктів реакції (більш ніж 90\%), свідчать про великий синтетичний потенціал даного методу, що однозначно заслуговує на всебічне та цілеспрямоване дослідження.

Ключові слова: асиметричний синтез; альдольне приєднання; специфічні неприродні амінокислоти; Ni(II) комплекси; основи Шифа; каскадні/доміно/тандемні реакції. 